\title{
Freshwater crabs of Vietnam: diversity and conservation
}

\author{
Cua nước ngọt ở Việt Nam: đa dạng và bảo tồn \\ Review paper \\ Do, Van $\mathrm{Tu}^{*}$
}

Department of Aquatic Ecology, Institute of Ecology and Biological Resources, 18 Hoang Quoc Viet, Ha Noi, Vietnam

\begin{abstract}
The freshwater crab fauna of Vietnam has a high diversity and endemism, 49 species have been recorded and 42 of them are only known from this country. In addition, many species are undescribed or undiscovered while at least $10 \%$ of known species are facing extinction. Water pollution, urban, industrial and agricultural development, habitat loss and fragmentation, deforestation and overexploitation are the main threats to this fauna. The first conservation recommendation is keeping rain forest tracts large enough to maintain habitat and water quality for long-term survival of these crabs. More research on taxonomy, distribution, population dynamics, main pressures, conservation status are needed in order to assess conservation status and create efficient conservation actions for freshwater crabs in Vietnam.
\end{abstract}

Khu hệ cua nước ngọt ở Việt Nam có múrc độ đa dạng và đặc hũu cao với 49 loài đã đurợc ghi nhận, trong đó có tới 42 loài chỉ được biết đến ở Việt Nam. Ngoài ra, nhiều loài cua nuơóc ngọt còn chua được mô tả hay chưa được khám phá, trong khi có tới $10 \%$ trong tổng số loài đã biết đang phải đối mặt với nguy co tuyệt chủng. Ô nhiếm môi truờng nuớc, đô thị hóa, phát triển công nghiệp và nông nghiệp, noi sống bị phân mảnh và mất, phá rùng cùng với khai thác quá mức là những mối đe dọa chính đối với khu hệ này. Công tác bảo tồn truớc hết phải giũ cho diện tích rùng đủ lớn để duy trì chất luợng môi truờng sống cho sư tồn tại lâu dài của các loài cua này. Các nghiên cưu về phân loại học, phân bố, động lưc quần thể là rất cần thiết để đánh giá tình trạng bảo tồn và đura ra nhũng hành động bảo tồn hiệu quả cho các loài cua nuớc ngọt ở Việt Nam.

Keywords: freshwater crab, Vietnam, diversity, conservation

\section{Introduction}

Freshwater crabs are among the most important invertebrates inhabiting Asian inland waters. These large and conspicuous crustaceans are present in almost all freshwater habitats from mountain streams to large lowland rivers and smaller water bodies (Yeo et al. 2008).

The first study of freshwater crabs in Vietnam began in the nineteenth century. In 1869, A. M. Edwards described a new species Thelphusa longipes in Con Dao Island. In 1904, De Man published the survey results of the Pavie team on freshwater shrimp and crabs in Indochina, Thailand, Myanmar, and Malaysia (Mission Pavie - III, 1904), with 28 species freshwater crustaceans, including $3 \mathrm{crab}$ species (Parathelphusa sinensis, Potamon longipes, P. cochinchinensis). The results are considered the first data on freshwater crabs in this region. The number of species of freshwater crabs found in Vietnam has grown steadily and was revised by studies of both Vietnamese and foreign scientists (Milne-Edwards (1869), De Man (1898, 1904), Rathbun (1902, 1904, 1905), Balss (1914), Kemp (1923), Dang (1967, 1975, 1995), Bott (1966, 1967, 1968a,b, 1970), Tuerkay and Naiyanetr (1987), Dang and Tran (1992), Dai (1995), Ng and Kosuge (1995), Ng (1996), Yeo and Ng (1998), Yeo \& Quynh (1999), Yeo and $\mathrm{Ng}$ (1998a,b, 2003, 2005, 2007), Dang and Ho (2001, 2002, 2003, 2005, 2007, 2008), Ng and Yeo $(2001,2005)$, Yeo and Naruse (2007), Yeo (2010), Naruse et al. (2011), Shih and Do (2014)).

Most recently, in the monograph 'Freshwater shrimps and crabs in Vietnam (Palaemonidae, Atyidae, Parathelphusidae, Potamidae)', Dang and Ho (2012) published a list of 34 freshwater crab species from Vietnam. The authors included freshwater crab species that have been recorded in Vietnam to the present time, as well as discussing the 
taxonomy of this group in Vietnam. However, due to lack of specimens and data, these authors did not include many species that were described from Vietnam.

In general, the studies of freshwater crabs in Vietnam are limited, the available data does not fully reflect the diversity of freshwater crabs in this country, the information about the species is deficient and their taxonomy is out of date. In the past few decades, the degradation and pollution of the environment has placed many species of Vietnamese freshwater crabs in threatened status.

The main objectives of this project are to give an updated list of freshwater crabs which have been recorded in Vietnam, their conservation status and threats. Finally, to provide suggestions for the needed research and conservation methods for this group.

\section{Diversity of freshwater crabs in Vietnam}

Considering carefully all previous studies on freshwater crab of Vietnam, we have recorded 49 species of freshwater crab in Vietnam. They belong to 21 genera and two families: Gecarcinucidae (13 species) and Potamidae (36 species) (Table 1). The genera Indochinamon (9 species) and Somanniathelphusa (7 species) have a large number of species and need to be revised.

Compared with other countries in the Indo-Burma region (Vietnam, Thailand, Lao Peoples Democratic Republic, Cambodia and eastern part of Myanmar), the diversity of freshwater crab of Vietnam can be considered quite high and ranked only after Thailand with 107 species (Cumberlidge et al. 2012). Biodiversity of freshwater crabs and other organism is in relation to diversity of landscapes. Vietnam has floodplains, swamps, lakes, large lakes, moist forests, rivers, highlands and mountain (including limestone mountain) systems, etc. provide good habitats for many freshwater crab species.

Yeo and Ng (1999) used Thailand as a reference for estimating the number of freshwater crab species of Indochi- na by a formula $\left(1.8 \times 10^{-4}\right.$ species $\left./ \mathrm{km}^{2}\right)$. Based on this formula, we estimated that Vietnam (with an area of $331698 \mathrm{~km}^{2}$ ) should have about 60 species of freshwater crab. Thereby, the number of undiscovered species of Vietnam is still high. Indeed, at least 6 undescribed freshwater crab species are in our collection, deposited at Institute of Ecology and Biological Resources (IEBR).

The freshwater crabs of the Indo-Burma hotspot are highly endemic at the country level $-92 \%$ of the potamid species, and $76 \%$ of the gecarcinucid species endemic (Yeo et al. 2008, Cumberlidge et al. 2009). The number of endemic species of Vietnam is 42 species $(86 \%)$, and the remaining species ( 7 species) are only distributed in a few neighbouring countries (China, Thailand, Laos and Cambodia) (Table 1). This calculation showed the level of endemic freshwater crabs of Vietnam is expected to be very high. Freshwater crabs have high levels of endemism because of their life history characteristics of low fecundity, direct development and low vagility. They are endemic to their respective zoogeographical regions and are considered restricted in their distribution (Cox, 2001). Many freshwater crab species are found in only a few mountain areas of Vietnam and the distribution range estimated less than $20000 \mathrm{~km}^{2}$ such as Kukrimon cucphuongense, Nemoron nomas, Tiwaripotamon edostilus (Figure 1) and other species in this genus,.

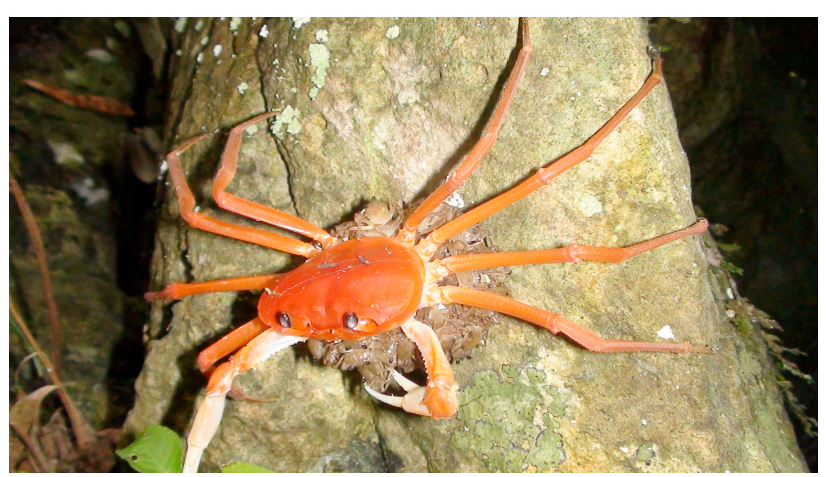

Figure 1. Tiwaripotamon edostilus from Cat $\mathrm{Ba}$ island, Vietnam

Table 1. The list of freshwater crabs of Vietnam and their conservation status and distribution (VU: Vulnerable; LR: Lower Risk; DD: Data Deficient; -: have not yet evaluation in IUCN Red List or Vietnam Red Data Book)

\begin{tabular}{|c|c|c|c|c|}
\hline $\mathbf{N}^{\mathbf{0}}$ & Taxon & $\begin{array}{l}\text { Red } \\
\text { Data } \\
\text { Book of } \\
\text { Vietnam } \\
(2007) \\
\end{array}$ & $\begin{array}{l}\text { IUCN Red } \\
\text { List } 2011 \\
\end{array}$ & Distribution \\
\hline & 1. GECARCINUCIDAE & & & \\
\hline 1 & Esanthelphusa dugasti (Rathbun, 1902 & & $\mathrm{LC}$ & $\begin{array}{l}\text { Vietnam, Laos, } \\
\text { Thailand }\end{array}$ \\
\hline 2 & Esanthelphusa prolatus (Rathbun, 1902) & & DD & Vietnam \\
\hline 3 & Guinothusa beauvoisi (Rathbun, 1902) & & DD & Vietnam \\
\hline 4 & Guinothusa harmandi (Rathbun, 1902) & & DD & Vietnam \\
\hline 5 & Mekhongthelphusa brandti (Bott, 1968) & & $\mathrm{LC}$ & Vietnam, Thailand \\
\hline 6 & Mekhongthelphusa neisi (Rathbun, 1902) & & $\mathrm{DD}$ & Vietnam \\
\hline
\end{tabular}




\begin{tabular}{|c|c|c|c|c|}
\hline $\mathbf{N}^{\mathbf{0}}$ & Taxon & $\begin{array}{l}\text { Red } \\
\text { Data } \\
\text { Book of } \\
\text { Vietnam } \\
(2007) \\
\end{array}$ & $\begin{array}{l}\text { IUCN Red } \\
\text { List } 2011\end{array}$ & Distribution \\
\hline 7 & Sayamia germaini (Rathbun, 1902) & & $\mathrm{LC}$ & $\begin{array}{l}\text { Vietnam, Thailand, } \\
\text { Cambodia }\end{array}$ \\
\hline 8 & Somanniathelphusa dangi Yeo \& Quynh, 1999 & & $\mathrm{LC}$ & Vietnam \\
\hline 9 & Somanniathelphusa kyphuensis Dang, 1995 & & DD & Vietnam \\
\hline 10 & Somanniathelphusa pax Ng \& Kosuge, 1995 & & $\mathrm{LC}$ & Vietnam \\
\hline 11 & Somanniathelphusa plicatus (Fabricus, 1798) & & DD & Vietnam \\
\hline 12 & Somanniathelphusa sinensis (H. Milne-Edwards, 1853) & & DD & Vietnam, China \\
\hline \multirow[t]{2}{*}{13} & Somanniathelphusa triangularis Dang \& Hai, 2005 & & $\mathrm{DD}$ & Vietnam \\
\hline & 2. POTAMIDAE & & & \\
\hline 14 & Balssipotamon fruhstorferi (Balss, 1914) & VU & DD & Vietnam \\
\hline 15 & Balssipotamon ungulatum (Dang \& Ho, 2003) & & $\mathrm{DD}$ & Vietnam \\
\hline 16 & Dalatomon laevior (Kemp, 1923) & & DD & Vietnam \\
\hline 17 & Dalatomon loxophrys (Kemp, 1923) & & $\mathrm{DD}$ & Vietnam \\
\hline 18 & Donopotamon haii Dang \& Hai, 2005 & & $\mathrm{LC}$ & Vietnam, Laos \\
\hline 19 & Dromothelphusa longipes (A. Milne-Edwards, 1869) & & DD & Vietnam \\
\hline 20 & Eosamon brousmichei (Rathbun, 1904) & & DD & Vietnam \\
\hline 21 & Hainanpotamon auriculatum Yeo \& Naruse, 2007 & & DD & Vietnam \\
\hline 22 & Hainanpotamon glabrum (Dang, 1967) & & $\mathrm{LC}$ & Vietnam \\
\hline 23 & Hainanpotamon rubrum Dang \& Tran, 1992 & & $\mathrm{LC}$ & Vietnam \\
\hline 24 & Indochinamon bavi Naruse, Nguyen \& Yeo, 2011 & & - & Vietnam \\
\hline 25 & Indochinamon сиа $($ Yeo \& Ng, 1998) & & VU & Vietnam \\
\hline 26 & Indochinamon dangi Naruse, Nguyen \& Yeo, 2011 & & - & Vietnam \\
\hline 27 & Indochinamon jinpingense (Dai, 1995) & & $\mathrm{DD}$ & Vietnam, China \\
\hline 28 & Indochinamon kimboiense (Dang, 1975) & VU & DD & Vietnam \\
\hline 29 & Indochinamon mieni (Dang, 1967) & & VU & Vietnam \\
\hline 30 & Indochinamon orleansi (Rathbun, 1904) & & DD & Vietnam \\
\hline 31 & Indochinamon phongnha Naruse, Nguyen \& Yeo, 2011 & & - & Vietnam \\
\hline 32 & Indochinamon tannanti (Rathbun, 1904) & $\mathrm{VU}$ & DD & Vietnam, China \\
\hline 33 & Kukrimon cucphuongense (Dang, 1975) & LR & DD & Vietnam \\
\hline 34 & Laevimon kottelati Yeo and Ng, 2005 & & DD & Vietnam \\
\hline 35 & Laevimon tankiense (Dang \& Tran, 1992) & & DD & Vietnam \\
\hline 36 & Larnaudia larnaudii (A. Milne-Edwards, 1869) & & DD & Vietnam \\
\hline 37 & Nemoron nomas Ng, 1996 & & VU & Vietnam \\
\hline 38 & Neolarnaudia botti Tuerkay \& Naiyanetr, 1987 & & DD & Vietnam \\
\hline 39 & Neolarnaudia phymatodes (Kemp, 1923) & & DD & Vietnam \\
\hline 40 & Planumon cochinchinense (De Man, 1898) & & DD & Vietnam \\
\hline 41 & Tiwaripotamon annamense (Balss,1914) & $\mathrm{VU}$ & $\mathrm{LC}$ & Vietnam \\
\hline 42 & Tiwaripotamon araneum (Rathbun, 1904) & & DD & Vietnam \\
\hline 43 & Tiwaripotamon edostilus Ng \& Yeo, 2001 & & VU & Vietnam \\
\hline 44 & Tiwaripotamon vietnamicum Dang \& Ho, 2002 & & DD & Vietnam \\
\hline 45 & Tiwaripotamon vixuyenense Shih \& Do, 2014 & & - & Vietnam \\
\hline 46 & Vietopotamon aluoiense Dang \& Ho, 2002 & & DD & Vietnam \\
\hline 47 & Villopotamon klossianum (Kemp, 1923) & & DD & Vietnam \\
\hline 48 & Villopotamon sphaeridium (Kemp, 1923) & & DD & Vietnam \\
\hline 49 & Villopotamon thaii Dang \& Ho, 2003 & & - & Vietnam \\
\hline
\end{tabular}




\section{Conservation status}

In the Vietnam Red Book (2007), 5 species of freshwater crab, account for $10 \%$ of all known freshwater crab species in Vietnam, 4 species were assessed as Vulnerable (VU), 1 species assessed as Lower Risk (LR). According to the IUCN Red List 2011, the numbers of threatened freshwater crab species in Vietnam were 4 species $(10 \%)$, all of them were assessed as VU, 9 species. (20\%) were assessed as Least Concern (LC) and 31 species (70\%) were assessed as Data Deficient (DD). No species of freshwater crabs from Indo-Burma region including Vietnam have been confirmed Extinct (EX) or Extinct in the Wild (EW). However, it should be noted that a species cannot be formally assessed as Extinct until exhaustive surveys have been carried out (Cumberlidge et al. 2012).

In the Indo-Burma region, the results of IUCN's freshwater crab assessment reveal current high levels of threat, with $36 \%$ of the assessed extant species for which sufficient data are available considered Threatened. There was insufficient information to assess the status of many species, which were categorized as Data Deficient (DD) due to a lack of specimens, and locality and population data, as the result of insufficient field surveys (Cumberlidge et al. 2009). It is of great concern that in many cases these DD species have not been found in recent years. If all Data Deficient (DD) species also prove to be threatened, the level of threat could be as high as $72 \%$ (Cumberlidge et al., 2012).

Recently, our surveys on aquatic fauna throughout the country displayed a strongly decline of distribution range and population size of almost all freshwater crab species. It means that the levels of threat for this group should be much higher than as we know. Hence, it is necessary to have more research to assess exactly the freshwater crab conservation status in the diversity hotspots of Vietnam.

\section{Major threats}

The present study was prompted by a growing awareness of the true extent of freshwater crab diversity and of the possible threatened status of many narrowly distributed species given the current widespread destruction of tropical forests and aquatic ecosystems (see review in Cumberlidge et al., 2009). Freshwater crab life history characterized by low fecundity, direct development, and low vagility, and niche specialization makes freshwater crabs highly susceptible to anthropogenic activities. While there is no clear evidence that any one species has been driven to extinction as a result, the threats facing many known species are critical. The main threats to freshwater crabs are deforestation, urban, industrial, agricultural development, aquatic habitat loss and water quality degradation and pollution (Cumberlidge et al. 2012). Besides, overexploitation should be also considered as most impacted factor for the decline of species of Gecarcinucid crabs because they are one of main protein sources for Vietnamese daily living. Moreover, when Gecarcinucid crabs become fewer, people start to catch other freshwater crab species for human consumption such as Indochinamon species.

\section{Research actions required}

Although Vietnam has a high aquatic biodiversity and high level of endemism of the freshwater fauna, the study of them is quite limited. There are still many new species yet to be described and many taxonomic issues are still unresolved. Moreover, data on the distribution, status, biology and ecology of freshwater crab species recorded in Vietnam is very limited. Several species are known only through the original description from the 19th century, and some species are known from only a few specimens obtained in a few random sampling locations. Additionally, specimen collections of freshwater crabs currently lack adequate specimens of many species.

There is a need for further surveys to discover new species, refine species distributions, define specific habitat requirements, describe population levels and trends, assess status, identify specific threats to Vietnam's freshwater crab fauna and suggest conservation methods and conservation areas (Cumberlidge et al., 2012).

\section{Conservation recommendations}

The rapid development of socio-economic pollution and destruction of the aquatic environment along with the overexploitation of fisheries resources has affected aquatic diversity in general as well as freshwater crabs in Vietnam. The population size of freshwater crabs living in the plains (like Esanthelphusa, Somanniathelphusa) fell significantly, some species are being bred in ponds to meet the needs of the people. Although no species of freshwater crab of Vietnam were ranked as Endangered in IUCN Red List and also in Vietnam Red Book, but the conservation measures for this species group are actually needed by high levels of endemism and restricted range of them. Restricted ranges of most species of freshwater crab will be the major issue for conservation. While a handful of freshwater crab species (belonging to Gecarcinucidae) living in the plains, in the rice fields and rivers have the ability to adapt and are more resistant to the changing environment, the majority of crabs in other freshwater habitats requires relatively clean and less disturbed waters. Thus, the conservation of freshwater crabs is to keep the natural forest area large enough to maintain good water quality for rivers and headwater streams.

The restricted range of many species, together with the on-going human-induced loss of habitat in many parts of the region, are primary causes of concern for the longterm survival of this fauna. Asia's freshwater crabs have a high degree of endemism with many species living in specialised habitats such as river rapids, lowland marshes, forested highlands, and islands. Additional research is recommended to determine the minimum effective size and design of protected areas for freshwater species such as crabs (Cumberlidge et al., 2012). 


\section{Acknowledgements}

This research is funded by Vietnam National Foundation for Science and Technology Development (NAFOSTED) under grant number 106-NN.05-2013.23. Many thanks to Arthur E. Bogan for his kind help in improving the English.

\section{References}

[1] Balss, H. (1914). Potamonidenstudien. Zoologische Jahrbucher. Abteilung fur Systematik, Ökologie und Geographie der Tiere 37, 401-410.

[2] Bott, R., 1966. Potamiden aus Asien (Potamon Savigny und Potamiscus Alcock) (Crustacea, Decapoda). Senckenbergiana biologica 47, 469-509.

[3] Bott, R., 1967. Potamiden aus Ost-Asien (Parapotamon De Man, Sinopotamon n. gen., Candidiopotamon n. gen., Geothelphusa Stimpson) (Crustacea, Decapoda). Senckenbergiana biologica 48, 203 220 .

[4] Bott, R., 1968a. Parathelphusiden aus Hinterindien (Crustacea, Decapoda, Parathelphusidae). Senckenbergiana biologica 49, 403-422.

[5] Bott, R., 1968b. Potamiden aus Süd-Asien (Crustacea, Decapoda). Senckenbergiana biologica 49, 119 130.

[6] Bott, R., 1970. Die Süßwasserkrabben von Europa, Asien, Australien und ihre Stammesgeschichte. Eine Revision der Potamoidea und der Parathelphusoidea (Crustacea, Decapoda). Abhandlungen der Senckenbergischen Naturforschenden Gesellschaft 526, 1338.

[7] Cox, C.B., 2001. The biogeographic regions reconsidered. Journal of Biogeography 28, 511-523.

[8] Cumberlidge, N., Ng, P.K.L., Yeo, D.C.J., Magalhaes, C., Campos, M.R., Alvarez, F., Naruse, T., Daniels, S.R., Esser, L.J., Attipoe, F.Y.K., Clotilde-Ba, F.-L., Darwall, W., McIvor, A., Baillie, J.E.M., Collen, B., Ram, M., 2009. Freshwater crabs and the biodiversity crisis: Importance, threats, status, and conservation challenges. Biological Conservation $142,1665-1673$.

[9] Cumberlidge, N., Ng, P.K.L \& Yeo, D.C.J., 2012. Chapter 6. Freshwater crabs of the Indo-Burma hotspot: diversity, distribution, and conservation. In: Allen DJ, Smith KG, Darwall WRT (compilers) The Status and Distribution of Freshwater Biodiversity in Indo-Burma. Cambridge, UK, and Gland, Switzerland: IUCN. Pp 102-113.

[10] Dai, A.Y., 1995. Five new species of freshwater crabs of genus Potamon from Yunnan Province, China (Crustacea: Decapoda: Potamidae). Journal of the Taiwan Museum 48, 49-59.

[11] Dang, N.T., 1967. The new fresh and brackish water species and genera of invertebrate fauna found in northern Vietnam. Journal of Biology and Geogra- phy, VI (3-4): 155-156 (in Vietnamese).

[12] Dang, N.T., 1975. Classification of freshwater shirmps and crabs from Northern of Vietnam. Journal of Biology and Geography. XIII, 3: 56-78 (in Vietnamese).

[13] Dang, N.T., 2012. On the taxonomical and nomenclatural status of genus Orientalia Dang, 1975 (Crustacea: Decapoda: Brachyura: Potamidae) from Vietnam. Journal of Biology, 34(3): 305-308 (in Vietnamese).

[14] Dang, N.T., Ho T.H., 2001. Freshwater crustacean. Volume V, Fauna of Việt Nam, Publishing House for Science and Technology, Ha Noi, 239 pp (in Vietnamese).

[15] Dang, N.T., Ho, T.H., 2002. Two new crab species of Potamidae found in Vietnam. Journal of Biology, 24(2): 1-8 (in Vietnamese).

[16] Dang, N.T., Ho, T.H., 2003. Two new potamid crab of Potamidae from southern part of Vietnam. Journal of Biology, 25(3): 7-13 (in Vietnamese).

[17] Dang, N.T., Ho T.H., 2005. One new genus and two new species of Potamid freshwater crab from southern part of Vietnam. Journal of Biology, 27(1): 1-7 (in Vietnamese).

[18] Dang, N.T, Ho, T.H., 2007. On new genus and one new species of freshwater crabs (Decapoda, Brachyura, Potamidae) from southern part of Vietnam. Journal of Biology, 29(1): 1-5 (in Vietnamese).

[19] Dang, N.T, Ho, T.H., 2008. On the taxonomy of freshwater crabs allied to the genus Potamon (Potamidae) in Vietnam, Journal of Biology, 30(2): 1217.

[20] Dang, N.T, Ho, T.H., 2012. Freshwater shrimps and crabs in Vietnam (Palaemonidae, Atyidae, Parathelphusidae, Potamidae) Publishing House for Science and Technology, $265 \mathrm{pp}$ (in Vietnamese).

[21] Dang, N.T., Tran, N.L., 1992. Two new freshwater crab species of Potamidae from Vietnam. Journal of Biology, 14(1): 17-21, f. 1-2 (in Vietnamese).

[22] Kemp, S., 1923. On a collection of river crabs from Siam and Annam. Journal of the Natural History Society of Siam 6(1): 1-42.

[23] Man, J.G. de, 1898. Notes sur quelques Thelphusidés recueillis par M. Pavie dans l'Indo-Chine. Bulletin de la Société Philomathique de Paris, Série 8 10(4): 36-52.

[24] Man, J. G. de, 1904. Crustacés décapodes terrestres et d'eau douce de l'Indochine. Mission Pavie (18971895), III, p. 311.

[25] Milne-Edwards, A., 1869. Révision du genre Thelphuse et description de quelques espèces nouvelles faisant partie de la collection du Muséum. Nouvelles Archives du Muséum d'Histoire naturelle, Paris 5: 161-191.

[26] Naruse, T., Nguyen Xuan, Q., Yeo, D.C.J., 2011. 
Three new species of Indochinamon Yeo \& $\mathrm{Ng}$, 2007 (Crustacea: Brachyura: Potamoidea: Potamidae) from Vietnam, with a redescription of Ranguna (Ranguna) kimboiensis Dang, 1975. Zootaxa, 33-48.

[27] Ng, P.K.L., 1996. Nemoron nomas, a new genus and new species of terrestrial crab (Crustacea, Decapoda, Brachyura, Potamidae) from central Vietnam. The Raffles Bulletin of Zoology 44, 29-36.

[28] Ng, P.K.L., Guinot, D., Davie, P.J.F., 2008. Systema Brachyurorum: Part I. An annotated checklist of extant brachyuran crabs of the world. The Raffles Bulletin of Zoology Supplement No. 17, 1-286.

[29] Ng, P.K.L., Kosuge, T., 1995. On a new Somanniathelphusa Bott, 1968, from Vietnam (Crustacea: Decapoda: Brachyura: Parathelphusidae). Proceedings of the Biological Society of Washington 108, 61-67.

[30] Ng, P.K.L., Yeo, D.C.J., 2001. A revision of the genus Tiwaripotamon Bott, 1970 (Decapoda: Brachyura: Potamidae), with a description of a new species. Journal of Crustacean Biology 21, 275-287.

[31] Rathbun, M.J., 1902. Description des nouvelles espèces de Parathelphusa appartenant au Muséum de Paris. Bulletin du Muséum national d'Histoire naturelle 3: 184-187.

[32] Rathbun, M.J., 1904. Les crabes d'eau douce (Potamonidae). Nouvelles Archives du Muséum d'Histoire naturelle, Paris, 4e série 6, 225-312.

[33] Rathbun, M.J., 1905. Les crabes d'eau douce. Nouvelles Archives du Muséum d'Histoire naturelle, Paris, 4e série 7, 159-322.

[34] Türkay, M., Naiyanetr, P.., 1987. The identity of Potamon rangoonense Rathbun 1904 and Thelphusa larnaudii A. Milne-Edwards 1869, with introduction of Neolarnaudia botti n. g. n. sp. (Crustacea: Decapoda: Potamidae). Senckenbergiana biologica 67 [for 1986]: 389-396.

[35] Yeo, D.C.J. 2010. A new species of Eosamon from southern Viet Nam (Brachyura, Potamidae), with notes on E. brousmichei (Rathbun, 1904). In: Fransen, C. H. J. M., S. De Grave and P. K. L. $\mathrm{Ng}$ (eds.), Studies on Malacostraca: Lipke Bijdeley
Holthuis Memorial Volume. Crustaceana Monographs 14:747-754.

[36] Yeo, D.C.J., Naruse, T., 2007. A revision of the freshwater crab genus Hainanpotamon Dai, 1995 (Crustacea: Decapoda: Brachyura: Potamidae: Potamiscinae) with a redescription of Potamon (Potamon) orientale (Parisi, 1916) and descriptions of three new species. Zoological Science 24, 11431158 .

[37] Yeo, D.C.J., Ng, P.K.L., 1998a. Freshwater crabs of the Potamon tannanti species group (Crustacea : Decapoda : Brachyura : Potamidae) from northern Indochina. Raffles Bulletin of Zoology 46, 627-650.

[38] Yeo, D.C.J., Ng, P.K.L., 1998b. Nomenclatural notes on Hainanpotamon Dai, 1995 (Brachyura, Potamidae), Orientalia Dang, 1975 (Brachyura, Potamidae) and Orientalia Radoman, 1972 (Mollusca, Gastropoda, Prosobranchia, Hydrobiidae). Crustaceana 71, 357-359.

[39] Yeo, D.C.J., Ng, P.K.L., 2003. Recognition of two subfamilies in the Potamidae Ortmann, 1896 (Brachyura, Potamidae) with a note on the genus Potamon Savigny, 1816. Crustaceana 76, 1219-1235.

[40] Yeo, D.C.J., Ng, P.K.L., 2005. On a new genus and species of freshwater crab from Vietnam, with comments on the nomenclatural status of Orientalia Dang, 1975 (Crustacea: Brachyura: Potamidae: Potamiscinae). Zootaxa 917, 1-15.

[41] Yeo, D.C.J., Ng, P.K.L., 2007. On the genus "Potamon" and allies in Indochina (Crustacea: Decapoda: Brachyura: Potamidae). The Raffles Bulletin of Zoology Supplement No. 16, 273-308.

[42] Yeo, D.C.J. and Ng, P.K.L. 2010. Guinothusa, a new genus of Indochinese freshwater crab (Decapoda, Gecarcinucidae). In: Castro, P., P. J. F. Davie, P. K. L. $\mathrm{Ng}$ and B. Richer de Forges (eds.), Studies on Brachyura: an Homage to Danièle Guinot. Crustaceana Monographs 11:353-366.

[43] Yeo, D.C.J., Ng, P.K.L., Cumberlidge, N., Magalhães, C., Daniels, S.R., Campos, M.R., 2008. Global diversity of crabs (Crustacea: Decapoda: Brachyura) in freshwater. Hydrobiologia 595, 275 286. 